DOI: $10.17805 / z p u .2016 .1 .16$

\title{
Русская диаспора в США: реакция общественных организаций на события на Украине и присоединение Крыма
}

\author{
А. Б. Ручкин \\ (ЦЕНТР ОБРАЗОВАНИЯ И КУЛЬТУРЫ «ГРИНТ», Г. МОСКВА)
}

В статье рассматривается деятельность организаций русской эмиграции в США в контексте общественной дискуссии по украинскому кризису и присоединению Крыма к России. Актуальность данной проблематики связывается с активным участием национальной диаспоры в поддержке внешнеполитического курса страны. Проблема "двойной лояльности" диаспоры по отношению к стране пребывания и стране исхода приобретает особую остроту в условиях ухудшения российско-американских отношений, роста подозрительности к любым видам российского информационного и культурного присутствия в локальном пространстве.

Общественная деятельность организаций русской диаспоры в США протекает в условиях раскола и крайней поляризации настроений русско-американской общины по украинско- 
му вопросу. Автор рассматривает общественные инициативы объединений различных эмигрантских волн, направленные против распространения русофобии в американском обществе. Очевидно, что консолидация пророссийской части общины происходит вокруг обновленного Координационного совета организаций российских соотечественников США при активном участии дипломатических представительств Российской Федерации. Мобилизация общественного мнения в поддержку российской позиции сопровождается ростом обвинений в формировании пятой колонны и ведении антиамериканской деятельности, что увеличивает политические и социальные риски для жизнедеятельности диаспоры. Автор формулирует необходимость перехода от чрезмерного огосударствления поддержки соотечественников к новому формату участия диаспоры в межгосударственном диалоге в рамках долгосрочного, проектного взаимодействия.

Ключевые слова: США; русская диаспора; русская эмиграция; русская иммиграция в США; общественные организации; соотечественники; российско-американские отношения

\section{ВВЕАЕНИЕ}

$\mathrm{M}^{\prime}$ ногомиллионная русская диаспора традиционно находится в поле зрения государственных институтов стран пребывания. Украинский кризис и присоединение Крыма к России в 2014 г. добавили новое измерение в восприятии глобального русского рассеяния. В общественном сознании стран пребывания обостряется беспокойство по поводу «двойной лояльности» диаспоры, разрыва между прежними и новыми, конфликтующими между собой эмоциональными привязанностями у ее членов (Engelbrekt, 2011: Электронный ресурс). В зарубежном медийном и экспертном сообществе все чаще вопросы, касающиеся русской диаспоры, рассматриваются через призму национальной безопасности и территориальной целостности того или иного государства. К изучению русского зарубежья активно подключаются «мозговые» центры военных ведомств. В докладе «Мобилизация соотечественников: стратегия, тактика и влияние России в бывшем Советском Союзе», подготовленном в ноябре 2015 г. для корпуса морской пехоты и флота США Центром стратегических исследований корпорации CNA (Вирджиния), sootechestvenniki (группа русских и российских эмигрантов) рассматриваются как важный глобальный ресурс российской политики, планомерная работа по мобилизации которого велась на протяжении последних десятилетий (Zakem, Saunders, Antoun, 2015: Электронный ресурс). Изучение этого ресурса представляется необходимым для принятия правильных тактических решений уже в ближайшем будущем. Русская диаспора перестает восприниматься как элемент внешнеполитических конструкций российского государства исключительно на постсоветском пространстве. Оппоненты российской власти из Института современной России П. М. Ходорковского (Нью-Йорк) подчеркивают глобальный характер противостояния России и Запада, отводят диаспоре важную роль в комплексной антизападной стратегии Кремля по милитаризации (weaponization; пер. наш. - A. P.) всех элементов информационного, культурного и финансового взаимодействия между странами (Pomerantsev, Weiss, 2014: Электронный ресурс).

В условиях противоборства мегадержав политические и социальные риски диаспоры значительно возрастают и чреваты внутри- и внешнеполитическими осложнениями. В связи с этим рассмотрение реакции русских общественных организаций в США на события периферийного для Америки, но крайне болезненного и близкого для России украинского кризиса представляется интересным и своевременным как для изучения современного положения этой группы в стране пребывания, так и ее отношения к внешнеполитическому курсу российского государства в условиях «асимметричной конфронтации» (Тренин, 2015: Электронный ресурс) между странами. 
РУССКАЯ АИАСПОРА В США В 2000-Е ГОАЫ:

В ПОИСКАХ САМОИАЕНТИФИКАЦИИ

Русская (Russian) диаспора в США насчитывает, по разным оценкам, от 3 млн (Belousova, 2012: Электронный ресурс) до 7 млн человек (Аенисенко, 2015а: Электронный ресурс). В эту категорию включают всех выходцев с территории Российской империи и Советского Союза, покинувших Родину в ходе одной из пяти эмиграционных волн ХХ в. Неудивительно, что община разделена по этническим и социокультурным признакам, не имеет общих политических целей ни внутри страны, ни за ее пределами. Электоральная активность, один из ключевых показателей социальной зрелости диаспоры в американском обществе, обозначена пока только в Нью-Йорке, где кандидаты от русскоязычной общины имеют опыт представления ее интересов в законодательных органах на уровне штата. Русский как язык внутригруппового общения, хотя и является одним из самых распространенных в США, соединяет, но не объединяет различные слои эмиграции. Прослеживается отчетливое деление на русскую и русскоязычную общины. В общественном пространстве все большее распространение получает термин «соотечественники». В августе 2014 г. V Форум соотечественников США был отмечен бурным обсуждением вопроса о том, кого можно относить к этой группе. Победили сторонники расширительного толкования этого термина, и теперь «соотечественники» в Америке - это не только эмигранты, получившие в США вид на жительство или гражданство, но и все выходцы из России, временно проживающие в Америке, в том числе по студенческой или рабочей визе.

Складывается впечатление, что русская диаспора в США, все более увеличиваясь количественно, теряет последние отличительные черты правового и этнического характера и по своей аморфности приближается к такому объединению, как Русский мир, в который входят «и соотечественники, и симпатизирующие, и специализирующиеся на России» (Косачев, 2012: Электронный ресурс), т. е. буквально все, кто интересуется Россией, вне зависимости от этнических, социальных и правовых характеристик.

Аля нас русская диаспора остается сетью общественных, культурных и образовательных учреждений, созданных выходцами из России в США в XX-XXI вв. для оказания помощи новым эмигрантам в правовой, социокультурной, профессиональной и политической адаптации к новой среде и в сохранении национальных традиций и обычаев (Зацепина, Ручкин, 2011). Ее национальный характер проявляется наиболее отчетливо в периоды так называемой этнической мобилизации, когда под влиянием переломных событий на Родине происходит самоопределение мигрантов по отношению к основным их действующим лицам и тенденциям, проявляется культурная близость и политическая лояльность к стране исхода.

Трагические события на Украине потрясли и разделили диаспору. Председатель Конгресса русских американцев Наталия Сабельник считает, что «большинство русских американцев все же остаются с Россией» (Славина, 2015: Электронный ресурс). Нью-йоркское интернет-издание «Русская реклама» ссылается на «некоторые опросы», дающие 65-процентную поддержку российской политики (Орлов, 2014: Электронный ресурс). Живущий сегодня в Нью-Йорке публицист В. Шендерович отмечает отсутствие единства, «сильную трещину <...> между русскими в эмиграции» и поражается количеству «пропутински настроенных эмигрантов» (Аенисенко, 2015b: Электронный ресурс). Обсуждение крымского вопроса выплеснулось на улицы американских городов. Прошли митинги поддержки России и протеста против российской 
оккупации украинского Аонбасса, акции русской и украинской диаспоры против фашизма и за демократический выбор Украины, сборы пожертвований для Украинской армии и АНР и $\Lambda \mathrm{HP}$, обращение с петициями к властям США, России и ООН.

Центробежная сила политических пристрастий разрывает на первый взгляд аполитичные культурные проекты. Эмигрантское литературное сообщество откликнулось на присоединение Крыма выпуском электронного сборника «НАШКРЫМ» (http://nkpoetry.com/) - антологии произведений 120 поэтов из России, Украины, Крыма, Аатвии, Германии, Италии, Франции, Ирландии, Америки, Австралии и Израиля. Сборник был призван стать «поэтическим миротворческим манифестом», возвращающим полуостров «из пространства раздора в пространство литературы и интеллектуального диалога, из геополитики в геопоэтику» (Идея проекта: Электронный ресурс). Миротворческий пафос сборника оказался похоронен в ходе последовавшего обсуждения. Интервью инициаторов издания, вошедших и не вошедших в него авторов, комментарии критиков и обозревателей вернули все на круги политического выбора «за» или «против», и стало очевидно, что для беспристрастного обсуждения прекрасного литературного начинания время еще не пришло.

\section{ОБЩЕСТВЕННЫЕ ОРГАНИЗАЦИИ РУССКОЙ АИАСПОРЫ: МИССИЯ - ЗАЩИТА НАЦИОНААЬНЫХ ИНТЕРЕСОВ}

Одним из первых в поддержку России после присоединения Крыма выступило Русское дворянское собрание в Америке (РАСА). Аеятельность организации, основанной в 1938 г., пронизана стремлением сохранить и передать новым поколениям русских американцев традиции российского дворянства, его мировосприятие, построенное на принципах чести, верности и служения. Президентом Русского дворянского собрания в Америке на протяжении последних лет является Кирилл Эрастович Гиацинтов, «потомственный эмигрант» (его родители покинули Россию в конце Гражданской войны). В мае 2014 г. на страницах нью-йоркского «Нового журнала», предоставившего свои страницы для отражения различных точек зрения на происходящее, он, «потомок русских офицеров, которые сражались еще с Оттоманской империей и, позднее, с Францией и Великобританией за сохранение Крыма в составе Российской империи», поделился своей радостью от преодоления исторической несправедливости передачи русского Крыма Украине в 1954 г. и решению «на референдуме воссоединиться с Россией» (Гиацинтов, 2014: Электронный ресурс). Отметив ведущуюся «хорошо синхронизированную организованную атаку на Россию, продолжающую вековую борьбу Запада и Католической церкви против нее», К. Э. Гиацинтов выразил надежду, «что эта унизительная и бесчестная пропаганда против России скоро прекратится, так как она не только ведет обе стороны деструктивным путем, но и игнорирует действительные, подлинные интересы России как независимой и выдающейся страны», и выступил за изложение в СМИ «правдивой картины происходящего» (там же).

Отношения Русского дворянского собрания в Америке и России складывались непросто, однако приверженность общим ценностям русской цивилизации, национальной культуре и патриотическим традициям воспитания предопределила сближение потомков белой эмиграции и новой Родины. Сегодня представители общества дорожат вниманием российского дипломатического представительства, так как видят в этом «восстановление исторической справедливости» после многих лет разделенного существования. Отрадно заметить, что и российские диппредставительства выра- 
жают признательность за поддержку страны. В мае 2014 г. Генеральный консул РФ в Нью-Йорке И. Голубовский в ходе торжественных мероприятий, посвященных 700-летней годовщине со дня рождения Преподобного Сергия Радонежского, передал руководителю РАСА К. Э. Гиацинтову благодарственное письмо министра иностранных дел С. В. Ааврова, в котором содержится также благодарность Президента России В. В. Путина (Осипов, 2014: Электронный ресурс). Русское дворянское общество в Америке, объединяющее ярких, самобытных людей, - это осколок той самой зарубежной России, которая почти столетие бережно хранит образ Родины, чувствует свою неразрывную связь с далекой страной и помогает в России тем, кому нужна поддержка. Традиции, связь поколений, верность убеждениям, понимание, что значит оставаться русским, привели их и к поддержке России в украинском вопросе.

Последовательным борцом с русофобией многие годы остается Конгресс русских американцев, который сегодня возглавляет Наталья Сабельник. Представитель второго поколения эмиграции (родилась в Китае, куда ее родители бежали после Гражданской войны, позднее переехала в США), она выросла в русской среде за границей, где «чемоданного настроения уже не было, но была ностальгия по стране, в которой мы никогда не были, но которую очень любили» (Игнатьева, 2015: Электронный ресурс).

Конгресс русских американцев (КРА) возник в начале 1970-х годов по инициативе Президента США Р. Никсона. Сформулированные тогда направления работы, среди которых сохранение русского духовного и исторического наследия, защита прав русских американцев, борьба с русофобией и развитие дружеских отношений между США и Россией, сохранили свою актуальность. За сорокалетний период КРА реализовал сотни благотворительных и просветительских проектов. Борьба за «русские права» не прекратилась и после распада СССР. Свою озабоченность ростом «антирусских настроений» и необъективностью освещения событий, связанных с Россией, КРА высказывал во время грузино-южноосетинского конфликта в 2008 г. (Конгресс ..., 2008: Электронный ресурс).

В июне 2014 г. КРА опубликовал открытое письмо Президенту США Бараку Обаме и Генеральному секретарю ООН Пан Ги Муну с требованием «немедленно прекратить массовое вторжение США на Украину» и «провокации против России». Как пишет $\Lambda$. Саенко, «в этом же письме высказана мысль, что аннексия Крыма вовсе не является нарушением международного права, поскольку границы между новыми государствами, сложившиеся в пределах бывшего СССР, не могут быть международно признанными и легко подлежат перекраиванию» (Саенко, 2015: Электронный ресурс). В октябре 2014 г. президент КРА обвинил американские власти в игнорировании мнения русских американцев, недовольных освещением в СМИ событий на Украине. Многочисленные петиции и запросы были оставлены даже без формального ответа (Бейненсон, 2015: Электронный ресурс). Аоббирование интересов русских американцев и улучшение имиджа России остается для организации одной из самых трудно реализуемых задач, важность которой значительно возрастает в новых условиях.

«Русская молодежь Америки» (РМА) - это одна из наиболее обсуждаемых сегодня организаций русской диаспоры, и причина тому - яркие массовые акции в НьюЙорке и его окрестностях, вызывающие интерес местных и российских СМИ. Миссия организации включает: «Укрепление единства русской молодежи в Америке. Приумножение и сохранение культурных, духовных и исторических ценностей русского наследия. Создание прочной основы для его преемственности» (Миссия: Электронный 
ресурс). Организация была учреждена в 2014 г. командой единомышленников под руководством Игоря Кочана, в течение долгого времени руководившего и продолжающего руководить отделом по работе с молодежью при Патриарших приходах в США (канонических подразделений Русской православной церкви). Сегодня PМА - светская организация, основные направления деятельности которой - проведение культурных, духовных и исторических программ, направленных на сохранение русского наследия (Цели: Электронный ресурс). Сверхзадача - изменить имидж России в глазах американцев (Ширинская, 2015: Электронный ресурс).

Аеятельность организации не ограничивается Нью-Йорком. Поддерживаются связи с молодыми соотечественниками в Орландо, Цинциннати, Вашингтоне; планируется открытие отделения в Сан-Франциско, взаимодействие с молодежными организациями других диаспор, а также России (Цели: Электронный ресурс).

Результатам деятельности РМА только за первый 2014 г. может позавидовать любая эмигрантская организация со стажем. «Русская молодежь Америки» с размахом провела акции, посвященные Аню Победы, включая раздачу георгиевских ленточек в разных частях города, несмотря на протесты антироссийских активистов, рассматривающих и пикетирующих празднование как пропаганду «коммунизма» и видящих в георгиевской ленточке «символ террористов, разжигающих огонь войны на востоке Украины» (Бурцев, 2015: Электронный ресурс).

«Русская молодежь Америки» демонстрирует приверженность уличным, почти карнавальным мероприятиям. Аень России отмечается шествием-парадом или хождением «"в народ”, к американцам» - это призвано напомнить, «что есть такая страна, огромная, и у этой страны есть свой день» (Ширинская, 2015: Электронный ресурс). Не прошло незамеченным в диаспоре проведение акции перед зданием ООН, посвященной «борьбе с возрастающим неофашизмом на Украине, в поддержку дружбы и сотрудничества между российским и украинским народами» (Результаты работы за 2014 г.: Электронный ресурс). «Аоброжелатели» объявили эти мероприятия проплаченными провокациями российского МИА, противопоставив им другие, «правильные» акции протеста, например против приезда российского лидера В. В. Путина в Нью-Йорк и его «агрессивной внешней политики», которая якобы «действительно отражает настроение русскоязычных соотечественников» (Иогинова, 2015: Электронный ресурс).

Молодые люди, принимающие участие в деятельности РМА, по-новому хотят взаимодействовать с Россией, предлагая проектную работу, построенную на взаимной заинтересованности. Многое будет зависеть от того, удастся ли организации установить, как она это планирует, связи с российскими молодежными организациями и сумеет ли определить общественные проекты, одинаково интересные для реализации молодым людям по обе стороны Атлантики.

Украинский кризис подтвердил еще раз, что между культурной близостью и политической поддержкой может пролегать пропасть. Отношение к вхождению Крыма в состав России развело по разные стороны баррикад людей и организации, наиболее тесно взаимодействовавшие с Россией в прежние годы, активно занимавшиеся популяризацией русского языка и историко-культурного наследия. Одни, как Объединенная российско-американская ассоциация, проводят праздники, символом которых становится инсталляция «Русский Техас - за мирный Аонбасс!» (КСОРС, 2014: Электронный ресурс), другие, как Пушкинское общество Америки, запускают информационные проекты «о борьбе Украины за свою независимость против российских со- 
ветских и постсоветских антигуманных догм и их современных апологетов» (Орлов, 2014: Электронный ресурс).

В контексте украинского кризиса крайне политизированным остается празднование окончания Великой Отечественной войны. Ааты и символика праздника разделили постсоветские диаспоры (Курзаков, 2015: Электронный ресурс). Русские общественные организации активно участвуют в подготовке и праздновании 9 Мая. Масштабы празднования Аня Победы в США с использованием новой российской (георгиевские ленты) и исторической советской символики свидетельствуют о поддержке национальных традиций со стороны значительной части диаспоры. Отметим, что первой из американских организаций, кто поддержал акцию РИА «Новости» «Георгиевская ленточка», стал Русско-американский культурный центр «Наследие» (г. Нью-Йорк). Вот уже 10 лет его представители распространяют ленточки на улицах Нью-Йорка и по США. В 2015 г. только по почте было распространено 15 тыс. ленточек.

Открытая поддержка позиции России по вопросу присоединения Крыма - это серьезный и ответственный шаг для эмигрантских организаций, обозначающий позицию, не совпадающую с политической линией страны пребывания. Многие организации на ранних этапах кризиса, в начале 2014 г., предпочитали не высказываться по этому вопросу. Как замечают местные обозреватели, «...многочисленные общественные организации, комитеты, фонды и землячества, заваливающие своими проектами народной дипломатии и требованиями о финансовой помощи всевозможные московские инстанции, предпочли хранить молчание, мотивируя таковое своим неучастием в политических процессах» (Осипов, 2014: Электронный ресурс). Эта тенденция проявилась и на уровне общественных институтов, призванных представлять диаспору в целом. Весной 2014 г. Координационный совет соотечественников в США, созданный и поддерживаемый Посольством России в Вашингтоне с 2006 г., устранился от выражения позиции по вопросу присоединения Крыма и оказался «единственным в мире, не поддержавшим консолидированное обращение советов всех стран к мировой общественности в отношении гуманитарной катастрофы на Юго-Востоке Украины и тревожного положения российских соотечественников в әтом регионе» (Тарасова, Тулина, Коротков, 2014: Электронный ресурс).

\section{РУССКАЯ АИАСПОРА И РОССИЙСКОЕ ГОСУААРСТВО: ПРИНЦИПЫ ВЗАИМОАЕЙСТВИЯ}

Бурное обсуждение текущей ситуации и выяснение, «кто за кого», состоялось в августе 2014 г. в Нью-Йорке на очередном V Форуме соотечественников США, оставившем после себя длинный шлейф взаимных обвинений и упреков.

Встреча представителей общественных организаций диаспоры прошла, по мнению Наталии Сабельник, в условиях «непростого времени», когда «из-за разных политических событий русскоязычные американцы разделились и по-разному относятся к происходящему» (Славина, 2015: Электронный ресурс). Чрезвычайный и Полномочный Посол РФ в США С. И. Кисляк приветствовал собравшихся участников и выразил надежду, что форум останется «механизмом», объединяющим соотечественников, а избираемый на нем страновой Координационный совет - «структурой, в первую очередь, призванной объединять диаспору, сохранять лучшие исторические и культурные традиции России, укреплять позитивный имидж России» (цит. по: Тарасова, Тулина, Коротков, 2014: Электронный ресурс). В последовавших выступлениях 
российская сторона призывала к консолидации общины, партнерскому взаимодействию с Россией, включающему набор взаимных обязательств. Представители МИА и ранее неоднократно говорили об ожидании от диаспоры «глубокой внутренней моральной поддержки, понимания <...> внешнеполитических инициатив и той созидательной работы, которая развертывается на огромных пространствах страны» (Болдова, 2014: Электронный ресурс). Большинство представителей эмиграции высказалось в поддержку усилий по консолидации общины. На форуме был избран новый состав Координационного совета организаций российских соотечественников. Совет последовательно призывает к мирному разрешению конфликта и скорейшему преодолению гуманитарной катастрофы. Этот подход отражает общее настроение диаспоры и ее надежды на прекращение этого трагического для двух народов противостояния.

В контексте украинского кризиса настойчивое стремление российского МИА консолидировать эмиграцию на пророссийской платформе было воспринято соотечественниками неоднозначно. Часть присутствовавших на форуме увидела в этом «попытку оказать политическое давление на русскоязычную общину США» и обвинила посольство РФ в США в создании пятой колонны из иностранных агентов, камуфлирующих «свои политические идеи под культурно-образовательные мероприятия» (Бурцев, 2015: Электронный ресурс). Отметим, что не все присутствовавшие признали итоги перевыборов. Председатель прежнего совета больше года ведет непримиримую общественную и личную борьбу со своими бывшими коллегами, считая решения форума нелегитимными. Смешение личного и общественного - традиционная для эмиграции ситуация. При накале общественных страстей одно часто трудно отделимо от другого, и потребуется время или новые обстоятельства, чтобы примирить враждующие стороны.

В условиях кризиса деятельность российских государственных структур была направлена преимущественно на консолидацию общины и выработку общей позиции по актуальным для внешнеполитической повестки вопросам. На второй план, как показывают материалы форумов соотечественников, отошли задачи по сохранению историко-культурного наследия, популяризации русского языка, развитию двусторонних контактов. Поддержка значительной части диаспоры российской внешней политики не означает преодоления внутренней разобщенности эмиграции. Объединение диаспоры на местном уровне для большинства стран дальнего зарубежья оставалось несбыточной мечтой на протяжении всего XX в., что не исключало всплески объединительных усилий и «этнической мобилизации» во время наиболее значимых событий отечественной истории. Русская диаспора в США пережила такие подъемы общественного интереса и поддержки Родины во время революционного подъема 1917 г., когда трудовые мигранты из Российской империи в едином порыве приветствовали демократические перемены; после нападения Германии на Советский Союз, когда большинство эмиграции выбрало «оборонческую» позицию, что вылилось в акции поддержки, сбор помощи и т. д. Эти периоды, как правило, длятся ограниченное время, затем общественная активность снижается, уступая место разочарованию и безразличию.

В качестве примера проекта, направленного на развитие взаимодействия русских американцев со странами пребывания и исхода, можно рассматривать Месяц русскоамериканской истории. В 2012 г. Сенат штата Нью-Йорк поддержал инициативу Русско-американского культурного центра «Наследие» (РАКСИ) и коалиции из более 
40 русских и американских организаций штата Нью-Йорк и принял резолюцию по учреждению апреля ежегодным Месяцем русско-американской истории в штате НьюЙорк. Уже пять лет в этот весенний месяц на площадках города проводятся различные мероприятия, подчеркивающие вклад русских американцев в развитие науки, культуры и образования в США. Это начинание получило общественное признание российско-американского сообщества и дальнейшее развитие. В июне 2015 г. в штате Вашингтон была законодательно учреждена ежегодная Неделя русского наследия. Эти инициативы, лишенные конфронтационной составляющей, встречающие понимание и поддержку местных властей, могут стать платформой в том числе и для развития и укрепления двусторонних связей.

В настоящий момент основным партнером диаспоры является российское государство, которое взаимодействует с соотечественниками, по словам К. И. Косачева, напрямую через правительственные структуры (Химшиашвили, 2014: Электронный ресурс). В этих условиях избежать обвинений в формировании пятой колонны внутри того или иного государства практически невозможно. При дальнейшем ухудшении российско-американских отношений на русские общественные организации может обрушиться вся мощь законов, направленных для обеспечения национальной безопасности против «иностранных агентов». В 1920-е (период «красной угрозы») и 1940-е годы ( «борьба с коммунизмом») эта борьба приводила к полному замиранию общественной деятельности в русско-американской среде, и требовались десятилетия для возвращения к нормальным условиям деятельности.

Недостатки чрезмерного «огосударствления» взаимодействия с диаспорой отмечались руководителями российских профильных ведомств, признававших, что концепция «мягкой силы» подразумевает взаимосвязи между людьми, отход от пропагандистской модели, выстраивание широкой сети контактов, включение неправительственных некоммерческих организаций в этот процесс, создание посредников, «которые бы связывали государственные механизмы с общественными» (там же). По мнению К. И. Косачева, такие организации, «маскируя вовлеченность заинтересованных властей, делают соответствующие проекты привлекательными для тех, кто является их конечными участниками» (там же). Практика антикризисной мобилизации общественного мнения в поддержку российского внешнеполитического курса в 2014-2015 гг. подтвердила недостаточное развитие инструментов «мягкой силы» и обращение к привычному массированному использованию возможностей государственных ресурсов, в данном случае дипломатических представительств.

\section{ЗАКАЮЧЕНИЕ}

Обзор реакции ряда общественных организаций русской диаспоры в США на события политического кризиса на Украине и присоединение Крыма позволяет сделать некоторые выводы. Бурная общественная дискуссия разделила диаспору. Раскол отчетливо прослеживается в деятельности общественных организаций диаспоры, выступивших либо в поддержку российской позиции в украинском кризисе, либо против нее.

Восприятию российской точки зрения значительной части до этого политически аморфной диаспоры способствовала откровенно русофобская позиция зарубежного политического истеблишмента и средств массовой информации. Одностороннее освещение происходящих событий порождает у эмигрантской аудитории, информированной и образованной, недоверие и отторжение. Обострение русофобии в американском обществе вызывает к жизни традиционные механизмы защиты диаспорой своих 
интересов. Такие исторические организации эмиграции, как Русское дворянское собрание в Америке, Конгресс русских американцев, в течение десятилетий отстаивали права и интересы русских американцев, последовательно выступали за объективное освещение в СМИ событий, связанных с Россией. Поддержка России со стороны таких организаций является частью их миссии, проверенной временем.

Принципиально новым явлением для диаспоры представляется поддержка курса России молодежными организациями новейшей эмиграционной волны, по общественно-политическим предпочтениям значительно более близкой настроениям на Родине, чем в стране пребывания. Аеятельность «Русской молодежи Америки» отличает яркий медийный характер, готовность к взаимодействию с Родиной в условиях информационной открытости диаспоры, что может стать определенным вызовом для сложившейся системы. О необходимости преодоления шаблонов в работе с молодыми соотечественниками неоднократно говорилось в документах правительственных комиссий и ведомств. О том, как это будет реализовано на практике, станет ясно уже в ближайшее время.

Посткрымский период принес новое во взаимодействие российского государства и диаспоры. Российские дипломатические представительства заняли активную позицию по отстаиванию своего видения развития событий на Украине и использовали все доступные им средства для мобилизации русских американцев в поддержку нашей страны. В организационном плане это привело к активному участию в работе V Форума соотечественников и последующей поддержке обновленного состава Координационного совета организаций российских соотечественников в США. Русская община в США в лице ее главной общественной организации - Форума соотечественников присоединилась к глобальной русской диаспоре в поддержке внешнеполитического курса страны.

Выстраивание системы поддержки и взаимодействия организаций соотечественников должно проводиться с учетом истории формировании диаспоры, социальнодемографических характеристик различных эмиграционных волн. При взаимодействии с диаспорой важно учитывать множественную, иногда конфликтующую, идентичность русских эмигрантов и стремиться находить то общее, что связывает, а не разделяет. Мобилизация Русского мира для решения локальных внешнеполитических задач, несмотря на значимый пропагандистский эффект, в долгосрочной перспективе может привести к его распаду на множество конфликтующих между собой и Родиной общин и в конечном счете к потере доверия и интереса к происходящему в России. Формирование «лояльности» современной диаспоры к стране исхода возможно в результате отказа от преобладающей сегодня модели взаимодействия государства с диаспорой напрямую и установления партнерских отношений между широким кругом российских и эмигрантских организаций для длительного проектного взаимодействия. Поддержка российской внешней политики со стороны соотечественников, проживающих за рубежом, продемонстрировала привлекательность для них новой роли России в современном мире. Эта роль должна быть подкреплена многовекторным подходом к различным группам и организациям глобальной диаспоры для выстраивания прочных, взаимно обогащающих партнерских отношений.

\section{СПИСОК АИТЕРАТУРЫ}

Бейненсон, А. (2015) Интервью с председателем КСОРС Натальей Сабельник / А. Бейненсон (корр.), Н. Сабельник [Электронный ресурс]// КСОРС - Координационный совет органи- 
заций российских соотечественников США. 9 февраля. URL: http://ksors.org/interview-withthe-ksors-chair-natalie-sabelnik/ [архивировано в WebCite] (дата обращения: 10.12.2015).

Болдова, Е. (2014) МИА РФ: В Прибалтике 1,3 млн русских. Мы будем их защищать / Е. Болдова (корр.), А. А. Макаров [Электронный ресурс] // RuBaltic.Ru. 1 октября. URL: http://rubaltic.ru/article/kultura-i-istoriya/01082014-sootechestvenniki/ [архивировано в WebCite] (дата обращения: 10.12 .2015$)$.

Бурцев, В. (2015) Коммунисты, вперед! В Америке ждут Зюганова [Электронный ресурс]// Соотечественники в США. 23 июля. URL: http://compatriotsru.uanet.biz/russian/nashi-sootechestvenniki/nashi-sootechestvenniki-v-raznykh-stranakh-mira/kommunisty-vpered-v-amerike-zhdutzjuganova [архивировано в WebCite] (дата обращения: 10.12.2015).

Гиацинтов, К. (2014) Отклик на Крымский референдум [Электронный ресурс] // Новый журнал. № 275. URL: http://magazines.russ.ru/nj/2014/275/19g.html [архивировано в WebCite] (дата обращения: 10.12.2015).

Аенисенко, А. (2015а) Парадокс русских медиа в Америке: аудитория есть, СМИ - нет [Электронный ресурс] // Форум Daily. URL: http://forumdaily.com/paradoks-russkih-media-vamerike-auditoriya-est-smi-net/ [архивировано в WebCite] (дата обращения: 10.12.2015).

Аенисенко, А. (2015b) Виктор Шендерович о новых русских в эмиграции и блефе Путина / A. Аенисенко (корр.), В. Шендерович [Электронный ресурс] // Форум Daily. URL: http://forumdaily.com/viktor-shenderovich-o-novyh-russkih-v-emmigratsii-i-blefe-putina/ [архивировано в WebCite] (дата обращения: 10.12.2015).

Зацепина, О. С., Ручкин, А. Б. (2011) Русские в США: Общественные организации русской эмиграции в XX-XXI вв. Нью-Йорк : RACH-C Press. 290 с.

Игнатьева, О. (2015) Наталья Сабельник: «Я родилась в Шанхае, но своей родиной считаю Россию» / О. Игнатьева (корр.), Н. Сабельник [Электронный ресурс] // Русский век. № 3.7 апреля. C. 44-47. URL: http://ruvek.ru/?module=articles\&action=view\&id=9661 [архивировано в WebCite] (дата обращения: 10.12.2015).

Идея проекта [Электронный ресурс] // HАШКРЫМ. Из геополитики в геопоэтику. URL: http://nkpoetry.com/ [архивировано в WebCite] (дата обращения: 10.12.2015).

Конгресс русских американцев недоволен освещением местными СМИ событий на Кавказе (2008) [Электронный ресурс]// Первый канал. 31 августа. URL: http://1tv.ru/news/world/31054 [архивировано в WebCite] (дата обращения: 10.12.2015).

Косачев, К. И. (2012) Не рыбу, а удочку: В чем состоит особенность «мягкой силы» России [Электронный ресурс] // Россия в глобальной политике. № 4. 4 сентября. URL: http://globalaffairs.ru/number/Ne-rybu-a-udochku-15642 [архивировано в WebCite] (дата обращения: 10.12.2015).

Курзаков, А. (2015) Как в США прошли торжества ко Аню Победы [Электронный ресурс]// Форум Daily. URL: http://forumdaily.com/v-nyu-jorke-proshli-torzhestva-ko-dnyu-pobedy/ [apхивировано в WebCite] (Аата обращения: 10.12.2015).

Цогинова, О. (2015) Акция протеста в Нью-Йорке против выступления Путина в ООН [Электронный ресурс] // Радио Свобода. 28 сентября. URL: http://svoboda.org/media/video/ 27274939.html [архивировано в WebCite] (дата обращения: 10.12.2015).

Миссия [Электронный ресурс]// Русская молодежь Америки. URL: http://youngrususa.org/ index.php/o-nas/missiya [архивировано в WebCite] (дата обращения: 10.12.2015).

Орлов, В. (2014) «Сегодня мы все - украинцы» [Электронный ресурс]// Русская Реклама : газета. 16 сентября. URL: http://news.rusrek.com/ru/russkaya-obshina/sobytiya-russkaya-obshina/355950-qsegodnya-my-vse-ukrainczyq.html [архивировано в WebCite] (дата обращения: 10.12.2015).

Осипов, А. (2014) Аворянское собрание в Америке стало единственной русской общественной организацией США, поддержавшей политику Путина в отношении Украины [Электронный ресурс] // RUNYweb.com. 28 мая. URL: http://runyweb.com/articles/city/ny-news/russiannobles-of-america-became-the-only-russian-public-organization-the-us-supported-the-position-of- 
putin-in-the-russian-ukrainian-conflict.html [архивировано в WebCite] (дата обращения: 10.12.2015).

Результаты работы за 2014 г. [Электронный ресурс] // Русская молодежь Америки. URL: http://youngrususa.org/index.php/o-nas/rezultaty-raboty-2014-g [архивировано в WebCite] (дата обращения: 10.12 .2015$)$.

Саенко, М. (2015) Трансмировая синекура [Электронный ресурс]// Новое время. № 31 (380). 15 сентября. URL: http://newtimes.ru/articles/detail/102188/ [архивировано в WebCite] (дата обращения: 10.12 .2015$)$.

Славина, Н. (2015) Совет соотечественников: в США из РФ уезжают молодые профессионалы, готовые вернуться / Н. Славина (корр.), Н. Сабельник [Электронный ресурс]// ТАСС. 5 ноября. URL: http://tass.ru/obschestvo/2408122 [архивировано в WebCite] (дата обращения: 10.12.2015).

Тарасова, О., Тулина, Т., Коротков, Ю. (2014) «Аюбите Россию как россияне». Состоялся V Форум российских соотечественников [Электронный ресурс]// Русская Америка. 18 сентябpя. URL: http://therussianamerica.com/web_RusUSA/articles/953/1/ [архивировано в WebCite] (дата обращения: 10.12.2015).

Тренин, А. (2015) Принуждение к встрече: что дали переговоры Путина и Обамы [Электронный ресурс] // Московский центр Карнеги. 29 сентября. URL: http://carnegie.ru/publications/?fa=61434 [архивировано в WebCite] (дата обращения: 10.12.2015).

Химшиашвили, П. (2014) «В кризис в разы повысилась посещаемость курсов балета», Константин Косачев, руководитель Россотрудничества / П. Химшиашвили (корр.), К. И. Косачев [Электронный ресурс] // Ведомости. № 3547. 13 марта. URL: http://vedomosti.ru/newspaper/articles/2014/03/13/v-krizis-v-razy-povysilas-poseschaemost-kursov-baleta [архивировано в WebCite] (дата обращения: 10.12.2015).

Цели [Электронный ресурс] // Русская молодежь Америки. URL: http://youngrususa.org/ index.php/o-nas/tseli [архивировано в WebCite] (дата обращения: 10.12.2015).

Ширинская, Н. (2015) Андрей Форофонтьев: «Идея Конгресса в этом и есть: чтобы дюди встретились, узнали друг друга, обменялись идеями, мыслями, знаниями, опытом» / Н. Ширинская (корр.), А. Форофонтьев [Электронный ресурс] // Всемирный координационный совет российских соотечественников, проживающих за рубежом. Официальное интернет-представительство. 4 декабря. URL: http://vksrs.com/publications/andrey-forofontev-ideya-kongressa-vetom-i-est-chtoby-lyudi-vstretilis-uznali-drug-druga-obmenyalis-/ [архивировано в WebCite] (дата обращения: 10.12.2015).

Belousova, M. (2012) The Russian diaspora in the US [Электронный ресурс]// Russian Analytical Digest. № 107. January 27. P. 2-3. URL: http://www.css.ethz.ch/content/dam/ethz/special-interest/gess/cis/center-for-securities-studies/pdfs/RAD-107.pdf [архивировано в WebCite] (дата обращения: 10.12.2015).

Engelbrekt, K. (2011) Loyal, disloyal, torn or indifferent? Diaspora communities in the age of mega powers [Электронный ресурс] // IPSA - International Political Science Association. URL: http://paperroom.ipsa.org/papers/paper_26462.pdf [архивировано в WebCite] (дата обращения: 10.12.2015).

Pomerantsev, P., Weiss, M. (2014) The menace of unreality: How the Kremlin weaponizes information, culture and money : A special report presented by The Interpreter, a project of the Institute of Modern Russia [Электронный ресурс]// The Interpreter. URL: http://interpretermag.com/wpcontent/uploads/2014/11/The_Menace_of_Unreality_Final.pdf [архивировано в WebCite] (дата обращения: 10.12 .2015$)$.

Zakem, V., Saunders, P., Antoun, D. (2015) Mobilizing compatriots: Russia's strategy, tactics, and influence in the former Soviet Union / With contributions by D. Gorenburg and M. Markowitz [Электронный ресурс]// The Center for Naval Analyses. URL: https://cna.org/CNA_files/PDF/DOP2015-U-011689-1Rev.pdf [архивировано в WebCite] (дата обращения: 10.12.2015). 


\section{RUSSIAN DIASPORA IN USA: THE REACTION OF PUBLIC ORGANIZATIONS \\ TO THE EVENTS IN UKRAINE AND THE ACCESSION OF CRIMEA TO RUSSIA \\ A. B. RUCHKIN \\ (Grint Center for Education and Culture, Moscow)}

The article discusses the activities of Russian Americans' organizations in the context of public debate on the Ukrainian crisis and the accession of Crimea to the Russian Federation. The urgency of this problem is associated with the increasing role of the national diaspora in support of the nation's foreign policy. Problems of dual 'loyalty' of the diaspora - to the host country and homeland - have become particularly acute in the face of deteriorating Russian-American relations, the growth of suspicion to all types of Russian informational and cultural presence.

The activities examined in the article take place under the conditions of split diaspora and extreme polarization of the Russian-American community's views on the Ukrainian crisis. The author examines the social initiatives of the associations uniting emigrants of various 'waves' against the spread of Russophobia in American society. Consolidation of pro-Russian part of the community occurs around the newly reelected Coordinating Council of Russian Compatriots of the USA actively supported by the diplomatic representatives of the Russian Federation.

Mobilizing public opinion in support of the Russian position is accompanied by surging speculations about the 'fifth column' and 'un-American activities', which increases the political and social risks for the diaspora. The author concludes that Russia should move away from excessive state support of compatriots to the new format of the diaspora's participation in the inter-state dialogue in the framework of a long-term, project-based collaboration.

Keywords: US; Russian diaspora; Russian emigration; Russian immigration to the United States; non-governmental organizations; compatriots; Russian-American relations

\section{REFERENCES}

Beinenson, A. (2015) Interv'iu s predsedatelem KSORS Natal'ei Sabel'nik [Interview with the Chair of the Coordinating Council of Russian Compatriots of the USA Natalia Sabelnik]/ A. Beinenson (corr.), N. Sabelnik. KSORS - Koordinatsionnyi sovet organizatsii rossiiskikb sootechestvennikov SShA, February 9. [online] Available at: http://ksors.org/interview-with-the-ksors-chairnatalie-sabelnik/ [archived in WebCite] (accessed: 10.12.2015). (In Russ.).

Boldova, E. (2014) MID RF: "V Pribaltike 1,3 mln russkikh. My budem ikh zashchishchat'" [Ministry of Foreign Affairs, RF: "1.3 million Russians live in the Baltic states. We will be protecting them"]/ E. Boldova (corr.), A. A. Makarov. RuBaltic.Ru, October 1. [online] Available at: http://rubaltic.ru/article/kultura-i-istoriya/01082014-sootechestvenniki/ [archived in WebCite] (accessed 10.12.2015). (In Russ.).

Burtsev, V. (2015) Kommunisty, vpered! V Amerike zhdut Ziuganova [Communists, go forward! Zyuganov is expected in America]. Sootechestvenniki $v$ SShA, July 23. [online] Available at: http://compatriotsru.uanet.biz/russian/nashi-sootechestvenniki/nashi-sootechestvenniki-vraznykh-stranakh-mira/kommunisty-vpered-v-amerike-zhdut-zjuganova [archived in WebCite] (accessed 10.12.2015). (In Russ.).

Giatsintov, K. E. (2014). Otklik na Krymskii referendum [A response to the referendum in the Crimea]. Novyi zhurnal, no. 275. [online] Available at: http://magazines.russ.ru/nj/2014/275/ 19g.html [archived in WebCite] (accessed 10.12.2015). (In Russ.).

Denisenko, A. (2015a) Paradoks russkikh media v Amerike: auditoriia est', SMI - net [The paradox of the Russian media in America: There is an audience and there is no mass media]. Forum Daily [online] Available at: http://forumdaily.com/paradoks-russkih-media-v-amerike-auditoriya-estsmi-net/ [archived in WebCite] (accessed 10.12.2015). (In Russ.).

Denisenko, A (2015b) Interv'iu: Viktor Shenderovich o novykh russkikh v emigratsii i blefe Putina [Interview: Viktor Shenderovich on ?migr? 'new Russians' and Putin's bluff] / A. Denisenko (corr.), V. Shenderovich. Forum Daily [online] Available at: http://forumdaily.com/viktor-shenderovich-onovyh-russkih-v-emmigratsii-i-blefe-putina/ [archived in WebCite] (accessed 10.12.2015). (In Russ.). 
Zatsepina, O. S. and Ruchkin, A. B. (2011) Russkie v SSbA: Obshchestvennye organizatsii russkoi emigratsii $v X X-X X I v v$. [Russians in the USA: Public organizations of the Russian emigration in the 20th and 21st centuries]. New York, RACH-C Press. 290 p. (In Russ.).

Ignatieva, O. (2015) Natal'ia Sabel'nik: Ia rodilas' v Shankhae, no svoei rodinoi schitaiu Rossiiu [Natalia Sabelnik: I was born in Shanghai but consider Russia my motherland]/ O. Ignatieva (corr.), N. Sabelnik. Russkii vek, no. 3, April 7, pp. 44-47. [online] Available at: http://ruvek.ru/?module= articles\&action=view\&id=9661 [archived in WebCite] (accessed 10.12.2015). (In Russ.).

Ideia proekta [The concept of the project]. NAShKRYM. Iz geopolitiki $v$ geopoetiku [online] Available at: http://nkpoetry.com/ [archived in WebCite] (accessed 10.12.2015). (In Russ.).

Kongress russkikh amerikantsev nedovolen osveshcheniem mestnymi SMI sobytii na Kavkaze [Congress of Russian Americans is dissatisfied with the coverage of the events in the Caucasus by local mass media]. (2008) Pervyi kanal, August 31. [online] Available at: http://1tv.ru/news/world/31054 [archived in WebCite] (accessed 10.12.2015). (In Russ.).

Kosachev, K. I. (2012) Ne rybu, a udochku: V chem sostoit osobennost' "miagkoi sily" Rossii [Not the fish but the fishing rod: What is the feature of Russia's "soft power"]. Rossiia v global' noi politike, no. 4, September 4. [online] Available at: http://globalaffairs.ru/number/Ne-rybu-a-udochku-15642 [archived in WebCite] (accessed 10.12.2015). (In Russ.).

Kurzakov, A. (2015) Kak v SShA proshli torzhestva ko Dniu Pobedy [How the Victory Day was celebrated in the USA]. Forum Daily [online] Available at: http://forumdaily.com/v-nyu-jorkeproshli-torzhestva-ko-dnyu-pobedy/ [archived in WebCite] (accessed 10.12.2015). (In Russ.).

Loginova, O. (2015) Aktsiia protesta v N'iu-Iorke protiv vystupleniia Putina v OON [Protest rally in New York against Putin's speech at UN]. Radio Svoboda, September 28. [online] Available at http://svoboda.org/media/video/27274939.html [archived in WebCite] (accessed 10.12.2015). (In Russ.).

Missiia [Mission]. Russkaia molodezb' Ameriki [online] Available at: http://youngrususa.org/ index.php/o-nas/missiya [archived in WebCite] (accessed 10.12.2015). (In Russ.).

Orlov, V. (2014) "Segodnia my vse - ukraintsy" ["Today we are all Ukrainians"]. Russkaia Reklama, September 16. [online] Available at: http://news.rusrek.com/ru/russkaya-obshina/sobytiya-russkaya-obshina/355950-qsegodnya-my-vse-ukrainczyq.html [archived in WebCite] (accessed 10.12.2015). (In Russ.).

Osipov, A. (2014) Dvorianskoe sobranie v Amerike stalo edinstvennoi russkoi obshchestvennoi organizatsiei SShA, podderzhavshei politiku Putina v otnoshenii Ukrainy [Russian Nobility Association in America became the only Russian American public organization to support Putin's policy on Ukraine]. RUNYweb.com, May 28. [online] Available at: http://runyweb.com/articles/ city/ny-news/russian-nobles-of-america-became-the-only-russian-public-organization-the-us-supported-the-position-of-putin-in-the-russian-ukrainian-conflict.html [archived in WebCite] (accessed 10.12.2015). (In Russ.).

Rezul'taty raboty za 2014 g. [Results achieved in 2014]. Russkaia molodezb' Ameriki [online] Available at: http://youngrususa.org/index.php/o-nas/rezultaty-raboty-2014-g [archived in Web Cite] (accessed 10.12.2015). (In Russ.).

Saenko, L. (2015) Transmirovaia sinekura [The global sinecure]. Novoe vremia, no. 31 (380), September 15. [online] Available at: http://newtimes.ru/articles/detail/102188/ [archived in Web Cite] (accessed 10.12.2015). (In Russ.).

Slavina, N. (2015) Sovet sootechestvennikov: $v$ SShA iz RF uezzhaiut molodye professionaly, gotovye vernut' sia [Council of compatriots: Young professionals are leaving Russia for the USA but are ready to come back] / N. Slavina (corr.), N. Sabelnik. TASS, November 5. [online] Available at: http://tass.ru/obschestvo/2408122 [archived in WebCite] (accessed 10.12.2015). (In Russ.).

Tarasova, O., Tulina, T. and Korotkov, Yu. (2014) "Liubite Rossiiu kak rossiiane". Sostoialsia V Forum rossiiskikh sootechestvennikov ["Love Russia as Russians do". The 5th Forum of Russian compatriots took place]. Russkaia Amerika, September 18. [online] Available at: http://therussianamerica.com/web_RusUSA/articles/953/1/ [archived in WebCite] (accessed 10.12.2015). (In Russ.). 
Trenin, D. (2015) Prinuzhdenie k vstreche: chto dali peregovory Putina i Obamy [Enforced meeting: What comes out of Putin and Obama talks?]. Moskovskii tsentr Karnegi, September 29. [online] Available at: http://carnegie.ru/publications/?fa=61434 [archived in WebCite] (accessed 10.12.2015). (In Russ.).

Khimshiashvili, P. (2014) "V krizis v razy povysilas' poseshchaemost' kursov baleta", - Konstantin Kosachev, rukovoditel' Rossotrudnichestva ["Ballet courses have become much more popular during the crisis", the Head of the Federal Agency for the Commonwealth of Independent States, Compatriots Living Abroad, and International Humanitarian Cooperation (Rossotrudnichestvo) Konstantin Kosachev says]/ P. Khimshiashvili (corr.), K. I. Kosachev. Vedomosti, no. 3547, March 13. [online] Available at: http://vedomosti.ru/newspaper/articles/2014/03/13/v-krizis-v-razy-povysilas-poseschaemost-kursov-baleta [archived in WebCite] (accessed 10.12.2015).

Tseli [The goals]. Russkaia molodezh' Ameriki [online] Available at: http://youngrususa.org/index.php/o-nas/tseli [archived in WebCite] (accessed 10.12.2015). (In Russ.).

Shirinskaia, N. (2015) Andrei Forofont'ev: "Ideia Kongressa v etom i est': chtoby liudi vstretilis', uznali drug druga, obmenialis' ideiami, mysliami, znaniiami, opytom" [Andrei Forofontiev: "The idea of the Congress is to meet and get to know each other, to exchange ideas, thoughts, knowledge, and experience"]/ N. Shirinskaia (corr.), A. Forofontiev. Vsemirnyi koordinatsionnyi sovet rossiiskikb sootechestvennikov, prozbivaiusbchikb za rubezbom. Ofitsial'noe internet-predstavitel'stvo, December 4. [online] Available at: http://vksrs.com/publications/andrey-forofontev-ideya-kongressa-v-etom-i-est-chtoby-lyudi-vstretilis-uznali-drug-druga-obmenyalis-/ [archived in WebCite] (accessed 10.12.2015). (In Russ.).

Belousova, M. (2012) The Russian diaspora in the US. Russian Analytical Digest, no. 107, January 27, pp. 2-3. [online] Available at: http://www.css.ethz.ch/content/dam/ethz/special-interest/gess/cis /center-for-securities-studies/pdfs/RAD-107.pdf [archived in WebCite] (accessed 10.12.2015).

Engelbrekt, K. (2011) Loyal, disloyal, torn or indifferent? Diaspora communities in the age of mega powers. IPSA - International Political Science Association [online] Available at: http://paperroom.ipsa.org/papers/paper_26462.pdf [archived in WebCite] (accessed 10.12.2015).

Pomerantsev, P. and Weiss, M. (2014) The menace of unreality: How the Kremlin weaponizes information, culture and money : A special report presented by The Interpreter, a project of the Institute of Modern Russia. The Interpreter [online] Available at: http://interpretermag.com/wpcontent/uploads/2014/11/The_Menace_of_Unreality_Final.pdf [archived in WebCite] (accessed 10.12.2015).

Zakem, V., Saunders, P. and Antoun, D. (2015) Mobilizing compatriots: Russia's strategy, tactics, and influence in the former Soviet Union / With contributions by D. Gorenburg and M. Markowitz. The Center for Naval Analyses [online] Available at: https://cna.org/CNA_files/PDF/DOP-2015-U011689-1Rev.pdf [archived in WebCite] (accessed 10.12.2015).

Submission date: 12.12.2015.

Ручкин Александр Борисович - доктор исторических наук, директор Центра образования и культуры «ГРИНТ». Адрес: 111395, Россия, г. Москва, ул. Юности, д. 5, корп. 6). Тел.: +7 (499) 374-74-30. Эл. адpec: arouchkin@yandex.ru

Ruchkin Alexander Borisovich, Doctor of History, Director of GRINT Centre for Education and Culture. Address: Bldg.6., 5 Yunosti St., 111395 Moscow, Russian Federation. Tel.: +7 (499) 374-74-30. E-mail: arouch-kin@yandex.ru 